\title{
WALT WHITMAN AND FREDERICK DELIUS, ENDLESSLY ROCKING
}

\author{
O. Alan Weltzien
}

SEA-Drift, Walt Whitman's eleVen-poem compilation for the 1881 Leaves of Grass, has attracted several English and American composers, most notably Frederick Delius and Ralph Vaughan Williams. In fact, their respective adaptations of Whitman, both from Sea-Drift and elsewhere, represent one pinnacle of achievement in setting Whitman to music. In the very years that Vaughan Williams shaped his Sea Symphony (1903-1909), Delius's major Whitman work established his reputation not only in Germany but in his native land and elsewhere. These two Whitman advocates both adapted the closing of "A Passage to India," "Joy, Shipmate, Joy!" and "A Clear Midnight." For both, though, the Whitman of Sea-Drift figures most centrally in their careers and oeuvres. Clearly Whitman provided a freshening breeze for many English composers by the 1890s, but both Delius and Vaughan Williams felt a strong and lifelong personal identification with the poet. The year that Vaughan Williams began both his "Ocean Symphony" and serious folk-song collecting, 1903, was also the year Delius wrote Sea-Drift. ${ }^{1}$ Delius also came to Whitman early, during the years he discovered his own idiom, though we do not know exactly when he first fell under the spell of Leaves or "Out of the Cradle Endlessly Rocking." Delius's primary modern biographer, Christopher Palmer, states more than once that Whitman formed "one of Delius's three great literary loves," the others being Nietzsche and the Danish poet, Jans Peter Jacobsen. ${ }^{2}$ Explaining the particular affinity between Whitman, Vaughan Williams, and Delius, Palmer defines the composers' common disposition: "They are both great visionaries and mystics, happy like Whitman to view the sea as the symbol of man's spiritual odyssey into the unknown."3 Given this attitude about the sea, it comes as no surprise that Sea-Drift proves, for both, an essential text.

Delius uses Whitman's sectional title, though his Sea-Drift-first known to the world as Im Meerstreiben because of its May 24, 1906 Essen, Germany, premiere-treats only Whitman's famed leadoff poem, "Out of the Cradle." Significantly for Delius's subsequent reputation, by mid-1908 Sir Thomas Beecham had discovered Sea-Drift, waxing 
most enthusiastically to the composer: "I simply love Sea-Drift-have learnt it by heart \& you will be horrified to hear that I play it and sing it on the Piano to people up \& down the kingdom!!! Every one likes it! But I assure you that I have learnt all the harmonies quite correctly" (July 3, 1908). ${ }^{4}$ Before 1908 was out, Beecham conducted Sea-Drift twice, and for the next fifty-three years until his death, he proved Delius's most insistent advocate and popularizer. Beecham was instrumental in organizing the 1929 Delius Festival in London, and at that time Delius's friend and protégé Constant Lambert judged Sea-Drift one of Delius's greatest works. ${ }^{5}$

Sea-Drift stands as one of Delius's best scores: a judgment sustained by the composer, friends and biographers, and contemporary music critics. ${ }^{6}$ Older Delius biographers are curiously reticent about Whitman's influence on the composer. Beecham, for example, says nothing in general about Whitman in Delius's life, and Sir Eric Fenby says little. In his biography, however, Beecham summarizes the genesis of Delius's Sea-Drift: "A portion of [Whitman's] Sea Drift had captured and inflamed his imagination, and before the close of [1903] he had made not only sketches for a musical setting of the poem, but had formed in his mind an unusually clear conception of how it should be built."7 And Fenby, glancing across the first half of Delius's career, states that "Cradle" had become the perfect fit for the composer at that stage (1903): "the words and their emotional overtones are imaginatively apt for the 'Delius sound'; their arrangement invites a vocal line of irregular angularity-a kind of musical poetic-prose - such as he had been striving to achieve through the action of four operas." ${ }^{8}$ Curiously, up through 1908, Delius himself mentions Whitman in only one letter, yet he acknowledged Whitman's influence when recalling the genesis of the piece to Eric Fenby:

The shape of it was taken out of my hands, so to speak, as I worked, and was bred easily and effortlessly of the nature and sequence of my particular musical ideas, and the nature and sequence of the particular poetical ideas of Whitman that appealed to me. ${ }^{9}$

While in some respects a predictably stock response, Delius's account of the piece's origins points to a cross-disciplinary origin, one that merits close scrutiny. By assessing the "musical ideas" of "Cradle" and Delius's preferred "poetical ideas," we can better discuss Sea-Drift as an interdisciplinary entity. "Musical ideas" and "poetical ideas" correspond with one another to such an extent that neither seems complete without the other. Sea-Drift severely abridges "Cradle," setting only 101 of the poem's 183 lines (or a little over half), and it realizes the poem's lyrical intent differently than the poem by itself. The shortened poemas-musical-score represents the composer collaborating in the poet's corner, creating a work that lives between words and notes and magni- 
fies the poem's latent music. ${ }^{10}$

As is well known, Whitman proved typically forthright in his prefatory remarks by linking this "curious warble ... This wild and plaintive song" to music, stating that its "purport . . . eluding definition, is positive and unquestionable, like the effect of music" and "comes forth, as from recesses, by many repetitions." The poem as artifact resembles the birds" arias within "Cradle" and the hermit thrush's song in "When Lilacs Last in the Dooryard Bloom'd": such magical, even divine utterances invite deciphering, or "translation." Meaning and intention are present, even forceful, yet indirect if not heiroglyphic. There is nothing new about poetry aspiring to the condition of music, yet in Whitman we discern an unusual urgency and explicitness in the convergence that reverberates through his oeuvre. The key to the effect of "Cradle" lies in repetition wherein, for example, every formal element of the poem strives to imitate musical principles of organization such as cadence. ${ }^{11}$

Modern criticism has followed Whitman's prefatory cues for "Cradle." Decades ago, Leo Spitzer and Robert Faner established a professedly "musical" standard for reading the poem. Spitzer implies a false chronology of "detached musical pieces" which then "blend"; his "unendliche Melodie" and Wagnerian reference, however, close the slender gap between Whitman and Delius, as Sea-Drift certainly blends "nineteenth-century pantheism" with post-"Wagnerian orchestration." 12 What Spitzer deems a "symphony," Faner calls an "opera without music," with recitatives and arias "in the Italian style."13 Even if Faner's Italian emphasis is excessive, his overall conception reflects the poem's structure much more accurately than does the notion of symphony, which omits voice as the central presence. After all, "Cradle," particularly the first three quarters of it, does alternate between recitative and aria; when the "reminiscence" proper gets underway (1. $23 \mathrm{ff}$.), the first two pairs of recitative and aria (11. 23-31 + 32-40 and 41-51 + 52-54, respectively) foreshadow a longer recitative (11. 55-70) which functionally parallels the first (cf. 1l. 69-70 with 30-31) and in turn heralds the poem's longest aria (11. 71-129), in many respects the heart of the poem. Delius's abridgment, which begins with the first recitative (1.23) and ends after the central aria (1. 129), thus eliminating the poem's final 53 lines, intensifies the poem's structural repetitions. Unsurprisingly, recitative passages tend towards narrative framing and arias, towards lyrical comment. More obviously, the boy-narrator ostensibly owns the recitatives and "translates" the he-bird's arias (the two birds sharing only the first aria, 11. 32-40).

In the past decade or two, critics have shied away from Spitzer's and Faner's explicit musical analogies. But the emphasis in recent criticism on the disappearance of discrete identities and times (or tenses) within the poem nonetheless reinforces the sense that the poem imitates 
the felt wholeness of a musical piece-operatic or otherwise. ${ }^{14}$ Many years ago in The Design of the Present, John F. Lynen called Whitman "the master of every trick for concealing the forward thrust of sentences": "he makes the sentence itself seem suspended in mid-course." 15 Lynen identifies a central phenomenon in the Whitman line which, even as it moves forward syntactically and narratively, seemingly denies such linear momentum by invoking other reaches of time. That denial derives from Whitman's persistent departures from the apparently biographical and local; Janet S. Zehr, for example, believes the poem "very accurately" "represent[s] the process of remembering." 16 The blurring of identities and tenses in "Cradle" obviously generalizes the poem's experience from writer to reader and lends it symbolic if not didactic shape.

Sea-Drift furthers this process in crucial ways. Both poem and piece unfold chronologically yet grant the reader/listener rich visions of timelessness. The experience of aesthetic time in the piece complements that in the poem; the presence of a Delius working in the poet's corner suggests a symbiotic energy that underlines the formal claims of the poem. Just as present poet-speaker, boy, he-bird, and sea become one another, so the traditional distinction between recitative and aria tends to collapse and each overlaps the other. Aria and recitative balance each other such that the past is never ineluctably the past, because the recitatives-particularly the poem's longest one, following "The aria sinking"-with their "present energy" enfold the arias-the poem's Liebestod. ${ }^{17}$

In a parenthetical comment made long before writing his biography, Sir Thomas Beecham labeled Sea-Drift "the finest example in all music of the 'Arioso Recitativo'."18 At first glance the term appears selfcontradictory; upon closer inspection, however, it measures the structural repetitions and reciprocity of aria and recitative in "Cradle" and Sea-Drift. The New Grove Dictionary defines arioso recitativo as "a singing, as opposed to a declamatory, style of performance; a short passage in a regular tempo in the middle or at the end of a recitative." ${ }^{19}$ Such a definition describes, for example, the poem's second and shortest aria (11. 52-54), which begins the he-bird's lament and interrupts the boyspeaker's description of his physical and emotional closeness to the hebird. Arioso recitativo has metaphorical value if not literal application because it embraces the poet's musical ideas and the composer's poetical ideas; Sea-Drift's oscillation of solo voice with chorus, crossing the boundaries between aria and recitative, testifies to this value.

Apparent oppositions-poetical versus musical ideas, boy "translator" versus present speaker, past versus present, song versus recitation-function reciprocally, each energizing the other and gaining greatest relief only through the other. John Irwin reminds us that in Whitman, "poetic singing and poetic seeing are a mutually constitutive opposition": "phonic writing seeks to attain the self-evidential quality of a pic- 
tograph by achieving the self-referential quality of music." ${ }^{20}$ I believe the music of "Cradle" is more forceful than its formal visual claims. And Delius, a student of Nietzsche even more than of Whitman, playsfollowing Irwin's figure-Dionysus to Whitman's Apollonian art which continually strikes Dionysian effects. In 1903, the composer picks up where the poet left off, particularly in 1867, after seven years of intermittent revision. In his explanation of Sea-Drift's genesis quoted earlier, Delius describes himself as a collaborator of Whitman and subscribes to a romantic, organicist account of creation: the score determined its own shape just as for Whitman in "Cradle" or any other poem, the intentions generate the structure. ${ }^{21}$ Having surveyed Delius's attraction to Whitman, the genesis and subsequent reputation of Sea-Drift, and Whitman's musical intentions in "Cradle," let us glance in more detail at Delius's "poetical ideas" that animate Sea-Drift.

Inhabiting the fin de siecle musical world, Delius, like Debussy and others, strove to push out in new directions the sounds of Wagnerian romanticism just as Whitman, a couple of generations before, reinvented such staples as rhyme and stanza in poetry. Christopher Palmer describes the composer's fondness for what he calls "pentatonic figuration," which creates "a verticalization of the pentatonic scale" (the "sixth degree-tonic formula" represents one of Delius's signatures).$^{22}$ Delius's new language grafts Impressionistic techniques onto Griegian harmony as a way of expressing what many have called his nature mysticism. Palmer remarks that "Delius sought three principal themes in his literature: natural beauty, human love and the optimism born of self-reliance and earthly all-sufficiency." All three identify the composer as close kin to the poet, particularly to the degree that any given statement of one of these themes is couched in terms of "the mystic solitude endemic in untrammelled contact with nature"-a boy "blending myself with the shadows" along a nocturnal seashore, for example. Percy Grainger's definition of Delius's own psychological and musical landscape (and seascape $)^{23}$ belongs as well to Whitman - with the addition of the poet's insistently transcendental, unifying vision. In Sea-Drift, too, any sense of apartness - in the solo line, for example-disappears before the characteristic overlapping of solo, chorus, and orchestra, and these converging entities include the listener-reader.

Delius's nature mysticism manifests itself in what Grainger, trying to pinpoint the older composer's essential signature, called Delius's "free form-flow." This seemingly contradictory phrase fits both Delius's account of Sea-Drift's genesis and what is known about the evolution of Whitman's "wild and plaintive song." Grainger's adjective and coupled verb-noun further link Sea-Drift's musical effects with the verbal effects of "Cradle." Apparently untrammelled form - nothing less-articulates "untrammelled contact with nature" (of course, form is only apparently untrammelled). The ceaseless rhythms of sea and waves, the alterna- 
tions of recitative and aria- "the irregular ebb and flow of the harmony that is the prime structural factor"24-transform the linear chronology of love and death; Sea-Drift's music returns upon itself just as "Cradle" denies that the past is only, or even primarily, past. "Musical poeticprose," and "free form-flow" are interdisciplinary ideas that describe a new intimacy and dependency, for both poet and composer, on the other's art. Christopher Palmer speculates about the origins of Delius's "free form-flow" in a way that affirms the composer as the poet's disciple: "the saturated lyricism of his melodic writing is frequently a natural flowering from folksong, and in many of his works . . . there is an unmistakable aura of timelessness, an atmosphere of legend or myth." 25 Sea-Drift as a Delian effusion harkens back to folksong.

To the degree that Sea-Drift underscores "Cradle" as a Song of the Common Man, it probes the bonds between the autobiographical act, which generalizes an individual life story and forever recovers the past, and a particular myth that fuses perhaps our two most essential experiences, love and death. It is no accident that in the first biography of Delius (1923), Peter Warlock praises Sea-Drift as "the veritable drama of love and death, and image of the mystery of separation." ${ }^{26}$ Delius provides us another window into "Cradle" as a poetic statement of that peculiarly intense, nineteenth-century conflation of Eros and Thanatos, the liebestod.

\section{II}

Having traced some of the formal and philosophical affinities between "Cradle" and Sea-Drift in general terms, let us assess them in some detail. I have already remarked that Sea-Drift consists of three entities, in order of first appearance: full orchestra, chorus, and baritone solo. Generally the orchestra supplements the vocal textures, and can be compared to "Cradle's" frame: particularly the relation of the opening twenty-two lines to the pattern of recitative and aria that follows, and the relation of the closing fifty-three lines to the central aria (11. 71-129). The orchestra typically ushers in transitions in tempo markings or signals time or key changes; as a separate entity it functions most conspicuously in the opening and closing. Within the orchestra Delius occasionally employs a solo violin which heralds and complements the solo voice and thus stands in relief against both orchestra and chorus. ${ }^{27}$ As shall be seen, chorus and soloist share sections of recitative and aria. Sometimes the chorus responds in a choric style to the solo line; at other times it functions as equal partner, singing other lines; and in a few key spots such as the first aria (1. 32ff.) and "O rising stars" (1. 93ff.), the center of the central aria, it takes the lead. Imitating operatic style, Delius blends lines of text, and the effect further concentrates the blending voices in the poem. 
The formal energy of "Cradle" - the convergence of present adult and past boy-witness-translator, she-bird and he-bird and sea, and the oscillation of recitative and aria-manifests itself through the auditory imagination in Sea-Drift. For orchestra, chorus, and solo continually drift in and out of each other, discretely emerging then returning into a larger context of sound. Many moments in Sea-Drift show Delius as a superb sound painter, exploring a new maritime world. The essential auditory context in Delius's piece, the sounds of sea, suggest the sea as beginning and end, "the fierce old mother" or "old crone" out of and into which the self emerges/merges. And that context exists not as the flux and aimlessness of drift - the Whitman of "As I Ebb'd," for example-but as the swelling and receding associated with rocking. The pendulum rhythm of the cradle, harkening back to the alternating rhythm of waves and forward through the myriad oscillations governing one's lifespan, annihilates, ultimately, the clock's tick. The affirmative repetition of rocking, of systole and diastole, transcends the annulling repetition of ticking. Too, rocking orders drifting and endows it with purpose. Whitman's title describes a symbolic genealogy borne out by the poem's maternal metaphor (11. 133, 141, 182); Delius's retention of sectional title for his abridged "Cradle" points to origins, the wellspring of life, and merely masks the rhythm-first musical, then verbal —of drifting.

In Sea-Drift more obviously than in "Cradle," the "singer" is not "solitary," and its opening demonstrates the emergence of melody after the rhythmic fact. The human voice emerges out of and, at the piece's end, recedes into harmonic motions of instruments. For 45 measures (Moderato e tranquillo) the orchestra quietly creates a world and prepares for the voice(s) it will set in relief. That rhythmic world sounds both inhuman and human. Lower strings repeatedly play an afterbeat half-note, whole-note phrase suggestive of wave motion. High above it first flute, and then first oboe and clarinet variously play a seven- or eight-note phrase that descends well over an octave:

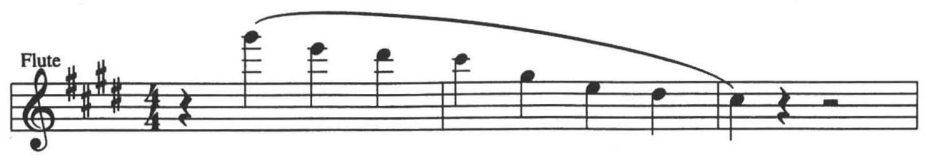

At Sea-Drift's outset, the composer begins to set the emotional landscape of "Cradle," wherein searing tragedy is softened to some extent by the joyous discovery of one's calling and solemn avowal to record the experience of tragedy. In Delius, Alan Jefferson remarks that descending figures, another Delius signature, "contribute largely to the poignant feeling inherent in the majority of his works. This is the "falling movement' which also gives the atmosphere of despair, even tragedy, when subtle harmonies are pressed into service as well." 28 The orchestral preamble, however, sounds more meditative than sad; certainly it is more 
muted than Whitman's virtuosic "proem"-overture. It establishes E Major as the piece's home key: a paradisal home, a visionary, idealized state of being. Whitman's "beginning notes of yearning and love there in the mist" (1. 11), or the he-bird's arias, become the falling figure in the woodwinds heard twice high above the quiet wave motions in the lower strings.

After four bars of quiet, preparatory woodwind chords, the chorus begins to "sing" the "reminiscence" in homophonic style which combines Romantic and Impressionistic sounds. At "Up this seashore" (1. $25 \mathrm{ff}$.) the voices enter in canon and soon thereafter, tenors (at "feather'd"), solo violin, ${ }^{29}$ and then soloist sing in quarter-note triplets, which Christopher Palmer calls the most essential Delius autograph. ${ }^{30}$ Whitman reinforces his boy/he-bird/she-bird trinity with the perfect repetition of "And every day" (11. 28-30): that effect carries forward through the three progressive verbs ("peering, absorbing, translating") that close the first recitative and the twice repeated command, "Shine!," that begins the first aria (1.32). Delius imitates the trinity with the baritone who, immediately upon entering, sings a quarter-note triplet on "every," as he does twice again on "every" and once on "cautiously." The solo voice enters, then, with line 28 , as the chorus finishes singing line 27; the overlap describes their initially complementary roles. The chorus has sung the first recitative's first five lines; the solo line inherits the choral function, singing the next four. A single voice needs to express the boy as "translator," yet it does not differ in kind from the chorus. The apparent silence of the she-bird, an unsettling moment (a tritone), is counteracted by the luminous cadence at "with bright eyes." Too, the solo violin's pentatonic triplets enhance the rapture of the birds' love and powers of generation. Of course, the boy-witness sees the nest and divines the meaning of the pair and their warmed eggs. Delius slows down each progressive verb (1. 31), giving "translating" two and onehalf bars, the center of which is in E Major, the home key of Sea-Drift. Music and poem both offer a mode of divination; E Major represents that access to mystical knowledge insistently advocated in the poem.

Unsurprisingly, Delius gives to the vocal ensemble the song shared by she-bird and he-bird. Yet even this lyric celebration of sun and unity shifts temporarily to the solo voice (1.38) before returning to the communal one. In Sea-Drift solo and ensemble share the narrative burden of recitative and the expressive burden of arias; here, for instance, both textures of voice jointly affirm the birds' bond which seemingly exists out of time. To mark this first chorus (Piu animato, forte), Delius has his chorus sing tonally, in simple rising intervals (e.g., the sopranos ascending an octave on "warmth, great sun!"). After this outburst, the mood changes slightly at "Winds blow south" (1. 36), and the rhapsodic solo violin again briefly enters, its pentatonic quarter-note triplets softening 
the threat of the elements. After the baritone's contribution, Delius changes the piece's rhythm for the first time, from $2 / 4$ to $6 / 4$, a more acute duple rhythm. The rhythm emphasizes this vision of unity, just as the preceding seven lines serve as preparation for these final two: "together" means "minding no time" and "singing all time." It begins as a round, sopranos and tenors leading off, then altos and basses entering two bars later, singing the same notes. After the chorus sings lines 3940 through, they repeat "Singing all time" then repeat "singing" four more times, after which all parts quiet, dropping a full octave over four bars. The composer stretches out the birds' song, unsurprisingly using the metaphor of singing to evoke a state of timelessness, a vision of oneness that can be expressed only as/through song.

The music exaggerates the intentions of the verse, making audible much of its potentiality. It does so as well with the sharp transition from aria back to recitative, from lyrical outpouring to chronology, from eternal joy to the tragedy of loss. In one and one-half orchestral bars Delius uses an operatic pause to jolt the listener to the baritone's news. The piece changes key and time, and in the forward march of $4 / 4$ the solo voice chromatically renders the poem's relentless negation (e.g., the thrice-repeated "Nor," 11. 44-45). Christopher Palmer believes, "The essential quality of Delius's chromaticism is that the harmony is chromatic, the melody not; wherever he does project a chromatic melody line he generally does so for coloristic purposes." 31 In these lines the minor third, usually a sound of sorrow, dominates (at "Till of a sudden," "One forenoon," and with greatest effect, "ever appear'd again," where the thin accompaniment furthers the voice's doom and its anguished eloquence).

Delius uses four bars of orchestral transition to return Sea-Drift to its initial time and key signatures and tempo marking (2/4, E Major, Molto tranquillo, respectively). The following section, describing the poem's "thenceforward" (i.e., the next verse paragraph, 11. 46-51), imitates the opening choral section in certain respects (e.g., the half-note rhythms in lower strings). That is, we hear the familiar made unfamiliar, as if the linear truth of mortality threatens the recursive impetus of piece and poem, the rhythm of rocking. These lines recall the first recitative's emphasis on the boy's secret, voyeuristic proximity to the magical birds. Of course the apparent similarity underlines the fatal difference; in the music a minor third, on "I saw" (precisely the same third as at "Till of a sudden" and "One forenoon," thus further unifying this recitative), announces the fact that two birds have become one bird. A change to a minor key and a poignant three-bar phrase on English horn also herald the solo's chromatic, octave descent ("the remaining one"). Yet the he-bird's identity remains solid in the face of loss, though it exists now solely as loss. Just as earlier solo and choral entries overlap, 
so now the composer overlaps the beginning of the poem's second (and shortest) aria with the end of the second recitative, which itself ironically echoes the first (cf. 11.51 with 26). Entities rock in and out of each other, creating ever richer resonances. The he-bird's plea with the winds, contrasting of course with the earlier joint appeal to the sun, begins in the chorus extremely softly, but halfway through Whitman's four "blows" the A-based minor key modulates to F Major and the rhythm again shifts to 6/4-as earlier at "Singing all time" (11. 39-40). Also as before, this choral section begins as a round and in imitation of the earlier shape, all four parts repeat the injunction, "Blow!," two or four times. But apparent repetition or recursion exposes difference, not sameness: this aria-a bit shorter, less blithe; sweeter and more pathetic-expresses the she-bird's death.

Contrary to the earlier time signature change between first aria and second recitative (11. 40-41), Delius now extends the 6/4 rhythm (Comodo) into the third recitative, narrated by the boy/soloist. That is, the timeless rhythm of song (e.g., "Singing all time" and "blow! / Blow up seawinds") intrudes into the narrative energy of recitative and slows it, further blurring any formal distinctions between them and underscoring the recitatives - the boy's "translations"-as song. Delius paints glistening stars (with two harps) and "slapping waves" (through woodwind afterbeats), and these lines rush to the rallentando that heralds the newly intimate bond between he-bird and boy (11. 59-60). The solo violin, playing high in its register, suggests the bird's "meanings" "pour[ing] forth" which the baritone alone can put into words. The composer affirms the privileged identity, the pride (1. 62) of the boy who, in some respects, now replaces the lost she-bird. The he-bird no longer sings alone, and Delius seals their bond ("my brother") by placing the solo voice high in its register, the F sharp on "I" being one of his highest notes in the piece:

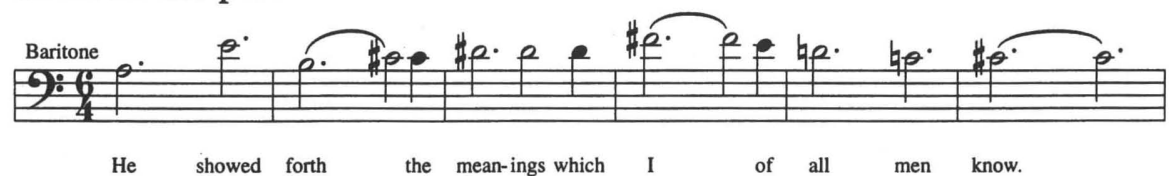

The durability of the birdsongs, the promise that the boy-man (1. 18) shall preserve their "meanings," transforms the earlier fact of annihilation, pitched just slightly lower in a minor key:

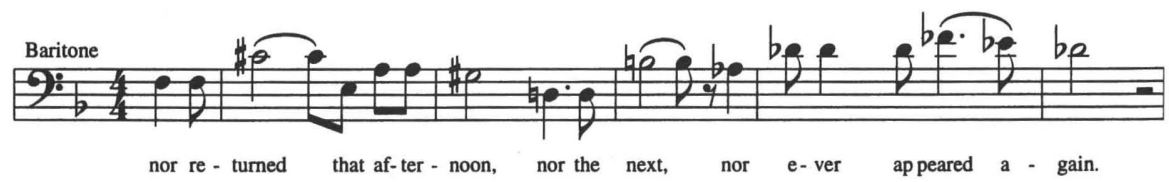

The proximity of the two phrases suggests, in musical miniature, the experience of "Cradle" that Sea-Drift extends: the transformation of 
loss, the rebuttal of death. After all, "to keep" is "to sing" (1. 69).

That rallentando stops time momentarily in Sea-Drift; the remainder (11. 61-70) of this third, longest recitative elaborates the boy's privileged identity as lover and "translator." Just as Whitman's affirmative "Yes" links sections of this recitative (11. 55, 61) with the second one (e.g., 11. 46-51), so Delius links these recitatives by now returning the piece to its original 2/4, E Major, Moderato, molto tranquillo sound. The duet between he-bird and boy continues, the pentatonic (quarter-note triplet) arabesques of the solo violin - the he-bird's "every note"-subsequently taken up by the two harps (parts of 1l. 63-65). The music links the boy's pride of place (a rising octave, low C-G-middle C, on "but I have treasur'd every") with one expression of the he-bird's identity (whole-note Cs an octave apart, 1. 50). The recitative enlarges the earlier descriptions of the boy's physical position along the shore, and the music, following suit, paints "the echoes, the sounds . . . after their sorts," particularly at "the breakers tirelessly tossing" and "the wind wafting my hair": at the latter moment Delius changes the time to 9/4, a triple rhythm befitting the new trinity of bird, boy, and sea. In SeaDrift the second recitative and aria (11. 51-52) overlap by just one measure, yet the piece as a whole depicts these contrasting vocal forms, graphically discrete in the poem, continually overlapping as arioso recitativo, as do the expressive burdens of baritone and chorus in the remainder. As in "Cradle," translator and translated exist just as much or more as one than apart. Solo voice and chorus collaborate more intimately than before, which manifests the intent of the third recitative (especially 11. 59-70). For example, while the chorus sings the he-bird's projection of amorous waves (11. 72-73), the baritone sings his different doom (1. 74).

In this aria the successive projections (waves, moon, sea, moon) attest to the bird's increasing desperation. In Sea-Drift several effects point the agitation. Strings play an increasingly loud "maritime" rhythm, and tubas play a syncopated figure that adds to the surging. The soloist takes the lead, jumping up and down an octave on "O madly the sea pushes upon the land," and the chorus echoes him at line 78 and with the phrases, "among the breakers," "in the white," "high and clear," and "who is here." Too, French horns and trumpet urge a short, rising chromatic eighth-note phrase at line 78. At Whitman's four times repeated "Loud!" - the adverb contrasting with the earlier repeated verbs, "Shine!," "Blow!," and "Soothe!," the contrast grammatically suggesting the bird's failed communication-Delius speeds up the final repetition and thus increases the note of urgency. This section of the aria draws to a fortissimo climax (Sea-Drift's loudest thus far) on line 85, where the $9 / 4$ rhythm slows into $12 / 4$ and chorus precisely doubles the baritone. Both textures of voice join together to declare unambiguously the he-bird's identity in the face of loss: 


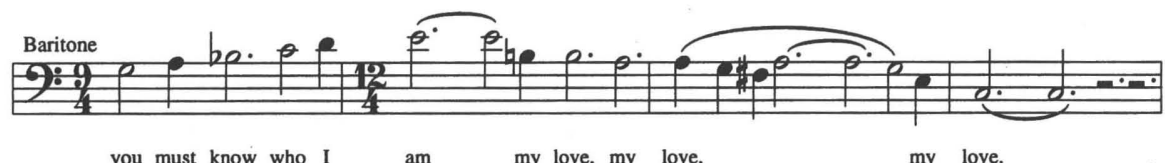

you must know who I am my love, my love,

my love,

And the loud orchestral cadence, stretched over 2 bars, further slows and emphasizes the desperately "shooting voice": the effect seems to freeze momentarily the piece's forward momentum, as if harkening back to the timeless $6 / 4$ rhythm concluding the first aria, shared by both birds, and present in the brief, second aria. The 3 elements of Sea-Drift join momentarily as one.

How might a composer sustain the drenched lyricism of the central, longest aria in "Cradle," "the song of my dusky demon and brother" (1. 175)? Delius elaborates Whitman's effects through a Tristan-like pattern of rising and falling emotion, of gradual crescendi followed by more rapid decrescendi. Particularly the Tristan of Act III serves as a model for the fusion of lines 71-85 and lines 93-119. The composer omits lines 86-92 and, across six measures of orchestral transition, returns SeaDrift to its home key and tempo-but now the chorus sings to the stars (1. 93) in a slow $6 / 4$, the rhythm of eternity. In the ensuing hush following the unified outburst (1. 85), Delius creates his most remarkable transition: now the soloist is absent and the accompaniment bare, and the chorus takes the lead, at times split into eight parts (11. 93-94). The unresolved ninth (at "O rising stars," "O trembling throat!," and "Pierce the woods, the earth!") expresses the unfulfilled aspiration of the mortal voice. When the soloist re-enters (with 1. 99) he does not alter their slow-moving homophony. Delius has the chorus sing lines 95-98 while the baritone sings lines 99-103. The composer thus reinforces the centrality of lines 99-104 for "Cradle," wherein Whitman repeats "carols" six times (moving through four adjectives). Delius does not "Shake out" songs of death; rather, in this tonal passage he juxtaposes the idea of death as song (i.e., the soloist) with the "throat" that "pierces" (i.e., the chorus). In fact, Delius extends this essential Whitmanian fondness for the throat that "shoot[s] my voice"- the origins of song and prophecy. Thus Sea-Drift unifies cornerstones of the Whitman credo: the power of song, of the "moved" voice, to record the conjunction of love and death. The baritone's apparent chromatic descent sounds above the basses' steadily downward chromaticism:

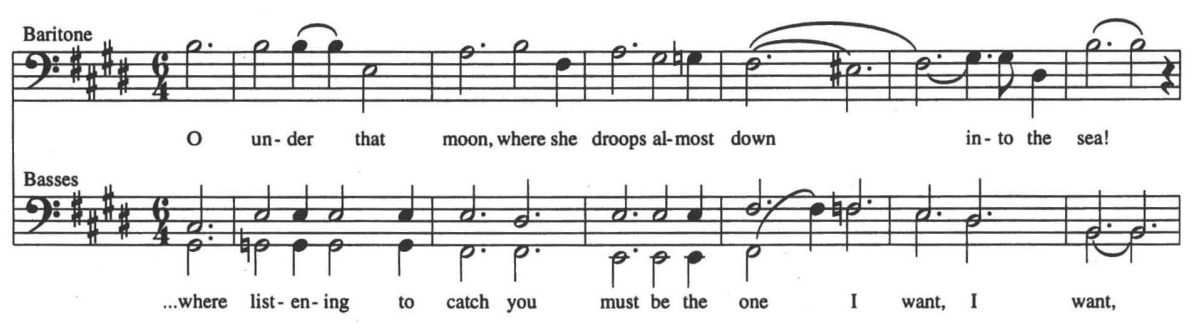


This radiant E Major chord, the most deliberately beautiful cadence yet heard, again stops time for a moment, expressing the tragedy of unresolved desire ("I want" facing the "waning moon" about merged with the sea, beginning and ending of all)..$^{32}$

The music flattens out the drama of the he-bird's sudden command for silence (1. 105). At the beginning of line 108, when the hebird pathetically defies the truth of loss with desire, Sea-Drift shifts for the first time to D Flat Major, a key rich with pathos, and we first hear that drooping quarter-note phrase that distills the "falling movement" heard in the beginning:

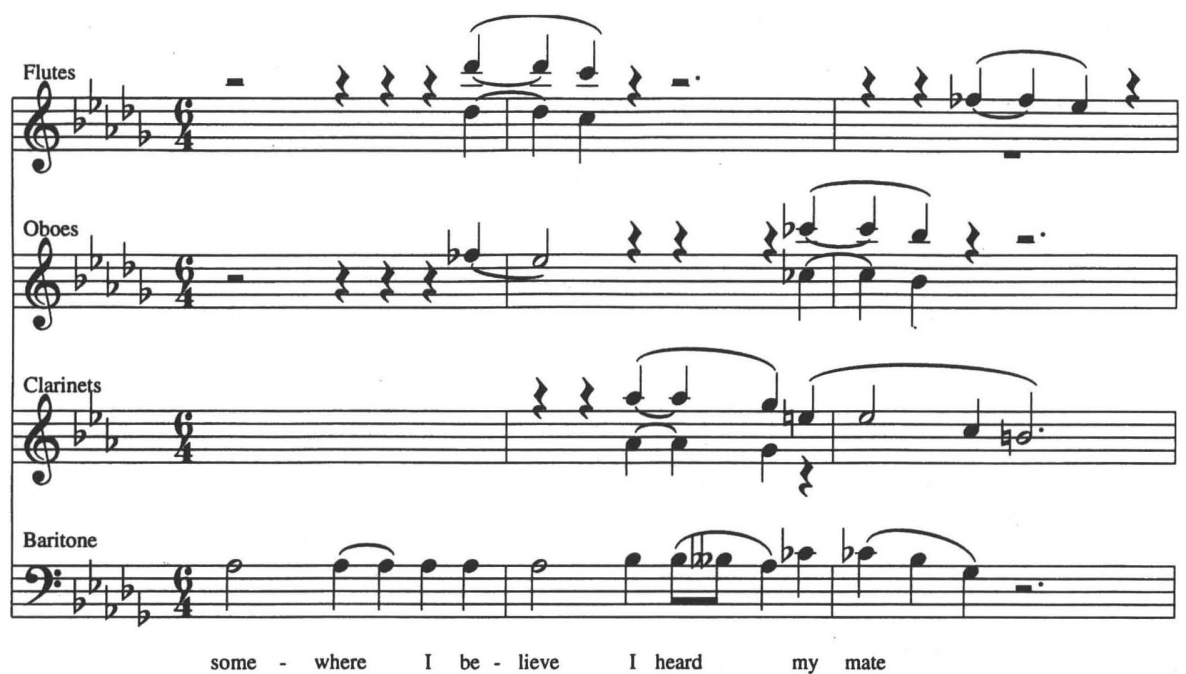

In some respects the phrase punctures the hope implicit in the baritone's "somewhere I believe" (1. 108). Delius again juxtaposes soloist (11. 111113) with chorus (11. 115-117), though now both do not always sing simultaneously. The choral undercurrent ironically pits the he-bird's faint "murmur" against his own sense of clarity (11. 97, 111-112). Delius evokes the strength of the he-bird's illusory hope in a couple of ways. The baritone closes line 110 ("immediately to me") with a sixteenthnote figure that depicts "immediately" and is immediately echoed in first French horn. Too, the baritone sings "Hither my love, / here I am" with firm resolve, the rallentando molto emphasizing the fusion of place and identity, thus echoing the big cadence in lines 84-85. Whitman's metaphors (e.g., "this just-sustain'd note," "This gentle call") again define the poem-as-song, and the composer matches the challenge, particularly in line 114 where, over steadily descending lower strings (as at 11. 98, 103), the solo voice floats, both reaching a luminous D Flat Ma- 
jor chord. But this pretty tribute to "you," the lost mate, lingers only briefly.

Whitman unites the final three verse paragraphs of the central aria in "Cradle" by leading each off with the rhetorical "O" (in fact six of the aria's final eleven lines begin thus, including the first five). This linkage brings into greater relief the swift modulation of emotions-from angry despair to a quieter futility and bittersweet recollection, to finally a quiet, sorrowful resignation-that climax "The aria sinking." In Sea-Drift the palette changes swiftly as well. After one bar of orchestral Largamente, the baritone angrily sings a chromatic line 119 which the chorus overlaps and repeats, the lower voices repeating "in vain" thrice as the orchestra, rising to triple forte, echoes these repetitions and climaxes the choral lament, its chord providing the loudest moment in the piece. Thus does the composer stretch the poet's line and point up the vanity of he-bird wishes. In the utter silence immediately following this cadence, the baritone sings, in chromatic descent - ad libitum: the he-bird's sorrow being as timeless as was his earlier joy— "O I am very sick and sorrowful" (1. 120).

The climax of the aria in "Cradle" stresses the ineluctable fact of loss; the climax of Sea-Drift stresses bitter anger ("O in vain!") as the he-bird recognizes the limitations of his "throat." The he-bird must musically grow, somehow, from anger to acceptance; he does so, of course, through his vocal organ, even as he denounces it: "And I singing uselessly, uselessly all the night" (1.124). We know the bird, through the boy/poet's agency, has got it exactly wrong. The power of song balances recollected joy (11. 125-127) with eternal sorrow (11. 128-129) and transcends the futility of the moment (1. 124). Following another orchestral transition, Sea-Drift shifts to C Major which functions as a way station during the bird/baritone's progress homeward to $\mathrm{E}$ Major, reached for the final verse paragraph (11. 125-129). The baritone now sings the short, "pathetically" drooping figure ("O brown halo") prominent in the orchestra since line 108, and he droops further during his final sublunary cry (11. 121-122):

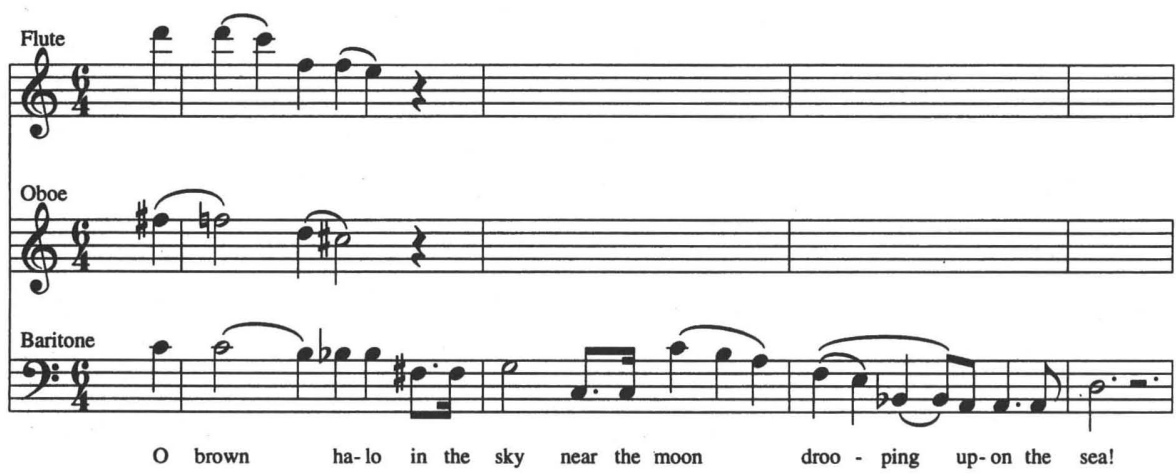


A final surge of anger stemming from failure (1. 123) links the poem's revision of line 95 (the "trembling throat!," conceived hopefully, now becoming the pained, "throbbing heart!") with the musical climax of anger heard at "in vain!" Now, however, the anger sounds smaller and briefer, and the voice falls on the repeated "uselessly" with resignation, not bitterness.

Excepting their reinforcement of the soloist's anger ("in vain!") in Sea-Drift's climax, the chorus, for the most part, drops out for the duration, its role being subsumed by the solo voice. The orchestra leads the piece home to E Major, and the slow 3/2 attests to a new union of birds and boy; or birds (as one), boy and sea; or boy, poet, and reader; or orchestra, solo and chorus (as one), and listener. In piece and poem, 3 moves fluidly into 2 and 2 into 3 . To climax his poem's birdsong, Whitman uses the rhetorical "O" thrice in a line (1. 125) celebrating union, which he extends with 3 prepositional phrases ("In the air, in the woods, over fields"), and subsequently balances with the thrice-repeated "no more" acknowledging separation. The "past" is the "happy life" manifested through "songs of joy" such as the timeless double time (6/4) of the first aria (11. 39-40). ${ }^{33}$ In the end is the beginning: as the baritone begins ("O past!"), first violins play a descending figure very close to that which begins Sea-Drift and first suggests its world of pathos. For the most part, strings follow the baritone's expansive ascent: the hebird's recognition that song resonates across space (1.126) and time (e.g., "Singing all time," 1. 39). Whitman balances "loved!," a past participial affirmation, against "death," that "low and delicious" noun also repeated five times (1. 173) that climaxes the long glossary-epilogue following the aria. In the piece, however, the modifier, itself no longer capable of a verb's action, glances back longingly to the repeated verbs ("Shine!," "Blow!," "Soothe!") that begin the poem's three bird-arias. Delius treats "loved!" trochaically, and the increasingly wide falling intervals from $\mathrm{E}$ climax the poignancy of loss:

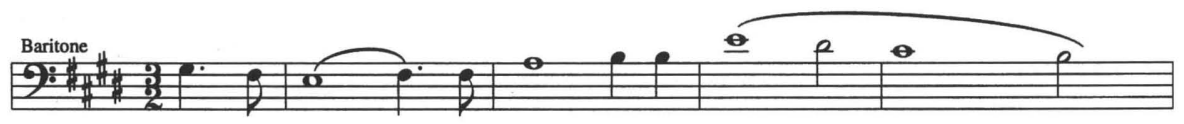

in the air, in the woods, 0 - ver fields,

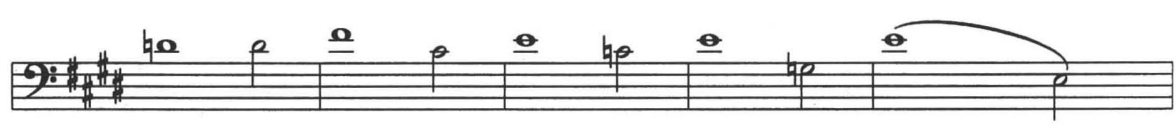

lo - ved, lo - ved, lo - ved, lo - ved, lo

The nobly resigned music, setting itself against the eternal ache of separation marked in the verse, contains the experience of loss within an abiding recollection of union-what, in part, the poem subsequently 
defines as "the fire, the sweet hell within" (1. 156). Delius repeats the aria's penultimate line ("But my mate no more, no more with me!"), as well as the final "no more" (1. 129), which the chorus very quietly repeats twice. So "no more," the essence of loss, outnumbers "loved!," the affirmation of union. But "loved!" is sung louder and higher; too, the baritone's first two expressions of "no more," half-note descents, give way to whole-note ascents and descents and, finally, a major third, sung more slowly. The soloist's final held E begins the orchestra's remarkable final passage which includes some magic seventh chords. In it the chorus - women, then men - very quietly breathe "No more" across the first half. Celli and basses play a similar afterbeat wave rhythm to that heard in the opening, their pedal effect now anticipating the final $\mathrm{E}$ Major serenity (second violins resolving the $\mathrm{E}$ Major $6 / 5$ suspension in the last bar). That rhythm and key remind us that time is cyclical, endlessly rocking, not linear; and that death, properly discerned, fits within it. The quiet frame of Sea-Drift contains the experience of love and death that the remainder of "Cradle" explicates.

"Cradle" and Sea-Drift, then, "rock" in exquisite complementarity. Formally and thematically, the composition realizes in any number of ways the poem's ebb and flow. The pulsations of Whitman's cadences, so full of latent music, gain relief in Delius's interplay of voice, chorus, and orchestra. The opera lover of the 1840s meets an alter ego in the opera composer of the 1890s, whose "free form-flow" in Sea-Drift restates the complex, intense architecture of "Cradle." As arioso recitativo it mediates between the apparent linearity of love and death and the eternal cyclical motions of sea and time. Its particular evocation of pathos poses one splendid adaptation of the poem's drenched lyricism.

Whitman's and Delius's status as soulmates merits further recognition and study. In spite of Sir Thomas Beecham's death (1961), Delius's reputation has steadily widened, but it has always been much stronger in Britain than in the U.S. Christopher Palmer remarks, "he must also have sensed that his music touched a nerve in England, and that England would remain loyal to him long after everywhere else had cast him aside. He sensed this dependence and he resented it . . ." 34 Other English conductors-Barbirolli and many current conductorshave recorded Delius, and in part because of such work Delius remains among the most important English composers of the early twentieth century. Christopher Palmer concludes his 1976 biography by proclaiming both Delius's cosmopolitanism and coterie appeal, ${ }^{35}$ but I think his audience grows. After all, the Chandos CD recording of Sea-Drift, conducted by Richard Hickox, won Gramophone's 1994 recording of the year: a fitting tribute to the remarkable collaboration of poet and composer in "Out of the Cradle Endlessly Rocking." 


\section{NOTES}

I would like to acknowledge the help of my colleague, Dr. Michael Fridley, Assistant Professor of Music at Western Montana College, in preparing the musical examples.

1 Michael Kennedy describes Whitman's appeal to the younger composer-folksong collector in terms that describes Delius's attraction as well: "Whitman presented a love of nature plus a combination of plain statement with mystical yearnings; he drew, like the folk singers, on vivid verbal material shorn of academicism. It is, therefore, significant that Vaughan Williams's first settings of Whitman were coincident with his first folk-song collecting year." Kennedy, The Works of Ralph Vaughan Williams, 2nd edition (New York: Oxford University Press, 1980), 82.

2 Christopher Palmer, Delius: Portrait of a Cosmopolitan (New York: Holmes and Meier, 1976), 7, 104.

3 Palmer, 147. Joseph G. Brennan also stresses the affinities between Whitman and Delius: "Both poets loved the sea, though with a landsman's love, and both used images of the sea as emblems of their deepest longing." (96) "Delius and Whitman," in Walt Whitman Review 18 (September 1972), 90-96.

4 Its premiere, conducted by Georg Witte, established Delius's reputation in Germany as a worthy alternative to Richard Strauss. Conductors Carl Schuricht and Fritz Cassirer, in letters to the composer (Schuricht to Delius, March 10, 1906 and March 12, 1908; Cassirer to Delius, October 6, 1906) expressed their high regard for SeaDrift. It was subsequently performed in Basle (March 1-2, 1907) by Hermann Suter and finally in English, under Sir Henry J. Wood's baton (in Sheffield, October 7, 1908). See Lionel Carley, ed., Delius: A Life in Letters, 1862-1908 (Cambridge: Harvard University Press, 1983), 270-272, 339-340, 359.

5 Constant Lambert cited the choral outburst at "Shine, Shine, Shine!," for particular praise: "Such moments strike too deeply to bear analysis." Lambert, "Apollo," 76 (November 1929).

6 In the recently published "Walt Whitman, Frederick Delius and English Music," Lionel Carley defines Sea-Drift as the "most nearly perfect marriage of words and music in the whole of Delius." (8) Carley, The Delian (June 1995), 3-9.

7 Sir Thomas Beecham, Frederick Delius (New York: Alfred A. Knopf, 1960), 122.

8 Sir Eric Fenby, Delius (New York: Thomas Y. Crowell, 1971), 56. See also Delius As I Knew Him (Cambridge: Cambridge University Press, 1936; 1981).

9 In a letter written to his wife, Jelka, from London December 18, 1898, Delius states, "I have my Walt Whitman and Nietzsche here so that I am not quite alone." Quoted in Carley, 8. Many years later, in a letter written to Ernest Newman (August 19, 1929) at the time of the 1929 Delius Festival, Delius confesses, "I composed 'Sea-Drift' in English and could not have done otherwise, as the lovely poem inspired my music." Quoted in Fenby, Delius As I Knew Him, 36.

10 Delius further extends, in certain spots, Whitman's 1867 practice of revision by added repetition. Such repetition, of course, defines musical rhythm even more than verbal rhythm.

11 In "Whitman and Speech-Based Prosody," D. R. Jarvis argues that "short syntactic units . . . provide the basic rhythmic unit in Whitman," and that "units of rhythm defined on phonological grounds coincide with these syntactic units." (58) See Jarvis, 
Walt Whitman Review 27 (June 1981), 51-62. C. Carroll Hollis's research on the "cursus," an oral rather than metrical rhythmic device (37-49), gives further credence to Whitman's valuation of the musical cadence over the line per se. Hollis concludes, "Whitman's perception that there was a midway point between journalism and oratory, on which a new kind of prophetic poetry might be based, was exactly right." See Hollis, Language and Style in Leaves of Grass (Baton Rouge: Louisiana State University Press, 1983).

12 Leo Spitzer, "Explication de Texte in Walt Whitman's Poem, 'Out of the Cradle Endlessly Rocking' " in ELH 16 (1949), 245-246.

13 Robert Faner, Walt Whitman and Opera (Philadelphia: University of Pennsylvania Press, 1951), 177.

14 According to Howard J. Waskow, the poem's narrator exists midway between observer and experiencer; he "defines his identity in a series of paradoxes. He is above all a blender of things." (128) See Waskow, Whitman: Explorations in Form (Chicago: University of Chicago Press, 1966). In "The Act of Remembering in 'Out of the Cradle Endlessly Rocking'" (Walt Whitman Quarterly Review 1 [September 1983], 21-25), Janet S. Zehr explores the poem's merging of past with present: "the process of creating a composite or totally fictional event to objectify repeated past events creates this [Augustinian] 'present of things past': this past very literally did not exist before the present" (24). In "Walt Whitman Passes the Full-Stop By . . .," Mark Kinkead-Weekes fuses the poem's tenses through its music: "Whitman starts with a splendid oratorio interweaving the senses and the tenses in music . . The past becomes actively present and the poet aspires to unite the here with the hereafter" (52). See Kinkead-Weekes in A. Robert Lee, ed., Nineteenth-Century American Poetry (London: Vision Press, Ltd., 1985). See also Jon Rosenblatt, "Whitman's Body, Whitman's Language" in Joann P. Krieg, ed., Walt Whitman: Here and Now (Westport, CT: Greenwood, 1985), 109.

15 John F. Lynen, The Design of the Present: Essays on Time and Form in American Literature (New Haven: Yale University Press, 1969), 325.

16 Zehr, 23. Michael Vande Berg defines "Cradle" as a contribution to elegiac and allegorical autobiography; in his source study he claims the poet's ambivalence towards his precursors accounts for "the curious way in which Whitman barely disguises his autobiographical intent.” See Vande Berg, “'Taking All Hints to Use Them': The Sources of 'Out of the Cradle Endlessly Rocking,' " in Walt Whitman Quarterly Review 2 (Spring 1985), 13. Vande Berg invokes Harold Bloom's concepts of "climanen" and "tessura" (from Anxiety of Influence) to probe Whitman's ambivalence about his literary models for "Cradle." Further, tracing an analogy between the mockingbird's song and Whitman's methods of composition, he sustains the blended voices within the poem: "the mockingbird's 'genius' . . . consists of his ability to imitate the songs of other birds and to intersperse these songs within his own" (16).

17 Kinkead-Weekes writes, "In the birdsong we are made to experience how the living present cannot be held, but turns agonizingly into the past with the inescapable fact of death. Conversely, in the "translation" we experience the opposite process as the past is made to live so vividly again that it becomes a mode of present energy" (53).

18 Quoted in the Evening Standard, January 13, 1927; reprinted in Christopher Redwood, ed., A Delius Companion (London: John Calder, 1976), 27. Delian Lionel Carley approvingly quotes Edward Carpenter, who before Beecham sensed Delius's unusual devotion to recitative:

'The 'deep pulsating music' that [Carpenter] finds in the poet is, [Carpenter] writes, 'often that of recitative - sonorous, bold, free, not returning into itself like a melody, but moving forward with suggestions of things to follow" "(Carley, 7-8). A recent musicolo- 
gist, Alan Jefferson, sustains this view: "Sometimes [Delius's melodies] are nothing more than melodic lines in the manner of recitative, especially when sung." See Jefferson, Delius, in The Master Musicians Series (New York: Octagon Books, 1972), 104.

19 By the late nineteenth century, composers infrequently employed arioso recitativo; in Bach, however, the style carries several distinct effects, sometimes serving "as the main body of a movement," or "the equivalent of recitativo accompagnato." Sea-Drift represents arioso recitativo in the spirit of Bach. See The New Grove Dictionary of Music (New York: MacMillan, 1980), 1:582.

20 In his meditation arising from "Cradle" Irwin elaborates this equivalence of auditory and visual image in Nietzschean terms. See Irwin, American Hieroglyphics (New Haven: Yale University Press, 1980), 100, 110.

21 Lionel Carley quotes Delius firmly linking arms with Whitman in their definition of form: "Defining form as 'nothing more than imparting spiritual unity to one's thought,' Delius acknowledged that form 'was contained in the thought itself, not applied as something that already exists.' 'Look at Walt Whitman,' he said. 'Whitman spent his whole life writing Leaves of Grass. It is his individual contribution to art. Nobody else could have written it. So with my own work.'" The composer-protégé could not describe a closer kinship between himself and the poet-mentor than this.

22 Palmer, 20-21.

23 Grainger wrote of his mentor after his death, "he naturally excels in the musical depiction of those moods that invariably accompany the 'nature' emotions: loneliness, wistfulness, dreaminess, turned-inwardness, vagueness, and a sense of distance." Quoted in Palmer, 82.

24 The New Grove Dictionary of Music, 5:341.

25 Palmer, 81.

26 Peter Warlock (Phillip Heseltine), Frederick Delius, reprinted and annotated by Hubert Foss (Westport, CT: Greenwood, 1974; 1977), 100.

27 References to the score taken from Frederick Delius, Sea-Drift, Conductor's Score (Miami: Edwin F. Kalmus \& Co., Inc., no date).

28 Jefferson, 97. This opening figure anticipates a shorter, richer descending figure, a tonal evocation of pathos, first heard as the baritone sings "For somewhere I believe I heard my mate responding to me" (1. 108).

29 Alan Jefferson states, "Delius employs the solo violin as he might a high soprano" (110).

30 Palmer states, "the ascending pentatonic triplet motif . . threads its way through Delius's life-work-the Delian fingerprint par excellence ...”" (55).

31. Palmer, 49.

32 Alan Jefferson cites this cadence when illustrating Delius's fondness for "falling movements." See Jefferson, 97. The tragedy grows explicit with line 104, an ironic comment on the E Major serenity just heard, full of descending figures that end on an accidental.

33 As Peter Warlock remarks, "The soul ... when all that it has loved and hoped for seems to have fallen away . . . rises again to re-create the past, to clothe it in a vesture of imperishable reality" (100). 
34 Palmer, 190.

35 Palmer, 191-193. 